\title{
Hematological Reference Ranges for Apparently Healthy Blood Donors in Debre Markos, North West Ethiopia, 2016
}

Mekuriaw Mesfin Birhan ( $\nabla$ mekuriawm@bdu.edu.et)

https://orcid.org/0000-0002-1208-9319

Tigist Tadele

Bahir Dar University

Diresbachew Haile

Addis Ababa University

Dessalegn Demeke

Bahir Dar University

Biruk Getahun

Bahir Dar University

Sefialem Assefa

Bahir Dar University

Research note

Keywords: Hematological profile, Blood donors, Debre Markos

Posted Date: July 31st, 2019

DOl: https://doi.org/10.21203/rs.2.12196/v1

License: (9) (i) This work is licensed under a Creative Commons Attribution 4.0 International License.

Read Full License 


\section{Abstract}

Objective The aim of this study was to determine hematological reference ranges for apparently healthy blood donors in Debre Markos, North West Ethiopia. Result A total of 250 adults with the median age of 20 (range 18 to 48 ) years were recruited. The mean \pm standard deviation of hematological values were white blood cells (WBC) count $6.34 \pm 1.82 \times 103 / \mu \mathrm{l}$ (males) and $6.96 \pm 1.89 \times 103 / \mu \mathrm{l}$ (females); absolute neutrophil count $3.57 \pm 1.47 \times 103 / \mu \mathrm{l}$ (male) and $3.99 \pm 1.38 \times 103 / \mu \mathrm{l}$ (females); absolute lymphocyte count, $2.09 \pm 0.64 \times 103 / \mu \mathrm{l}$ (males) and $2.27 \pm 0.68 \times 103 / \mu \mathrm{l}$ (females); absolute mid-sized cell count $0.68 \pm 0.36 \times$ $103 / \mu \mathrm{l}$ (males) and $0.70 \pm 0.37 \times 103 / \mu \mathrm{l}$ (females); red blood cell (RBC) count $5.13 \pm 0.49 \times 106 / \mu \mathrm{L}$ (males) and $4.57 \pm 0.36 \times 106 / \mu \mathrm{L}$ (females) platelets, $255.86 \pm 65.96 \times 103 / \mu \mathrm{l}$ (male) and $280.67 \pm 65.71 \times 103 / \mu \mathrm{l}$ (female).

\section{Introduction}

The International Federation of Clinical Chemistry defines "reference value" as the value obtained by observation or measurement of a particular type of quantity on a reference individual where the individual is selected using defined criteria ${ }^{1}$.

For appropriate diagnosis, treatment, and follow-up of patients, correct interpretation of the laboratory results is mandatory. This is attained by knowing the normal reference intervals that have been established at local setting than using values from other areas of the world which have different climate, socioeconomic status, living style and genetic makeup ${ }^{2}$.

In most African countries, however, reference intervals have not been adequately addressed. Instead, clinicians in those countries adopt the textbook reference intervals or from instrument manuals or publications $^{3,4}$ that were mainly obtained from European and American Caucasian populations ${ }^{5}$. Moreover, Published literatures have confirmed that many of the reference values obtained from the developed countries differ significantly from what pertains in most African localities ${ }^{2,6,7}$.

The hematological values which are currently in use in Ethiopia are also adopted from textbooks which refer mainly to Caucasian subjects. Adopting non-Ethiopian reference values for Ethiopians might be misleading.

Hence the present study was carried out to establish normal reference intervals for the hematological parameters in healthy blood donors in Debre Markos and compare the results against hematological values being used currently. The result can be used as reference values in the future evidence-based practices.

\section{Materials And Methods}

Facility based cross sectional study design and convenient sampling technique was employed. Apparently healthy blood donors, age between 18 and 65 years, residents of Debre Markos, consented to 
participate in the study and those with negative serological tests for viral infections and malaria were included in the study.

Data was collected from 250 subjects by questioner and observing medical records of the donors. Three $\mathrm{ml}$ of venous blood was taken with appropriate aseptic technique. The blood sample was collected by EDTA coated vacutainer tube. Within 5-8 hours of blood collection, samples were transported at room temperature in sealed boxes to Debre Markos Referral Hospital. Complete blood count analysis was performed using Auto Hematology Analyzer BC-2800 (Mindray). White blood cells, red blood cells and platelets were counted and sized by the impedance method. In order to maintain quality of the data, the performance of the hematology analyzer were controlled by running quality control measurements before analysis of the sample. The result was collected within six hours and filled on the data collection format.

Data was cleaned, edited, checked for completeness and entered into Epi Data version 3.1 and then transferred to SPSS version 22 for statistical analysis. In all the cases p-value of less than 0.05 was considered as statistically significant and $95 \%$ confidence level was accepted.

\section{Result}

A total of 270 donors participated in this study. Of this $8(3 \%)$ were excluded due to infection and $12(4.4 \%)$ were excluded due to sampling error. Thus data of 250, 192 male and 58 female, were included for final analysis. The age range of donors was between 18 to 48 years with mean age of $22.11 \pm 5.63$ years.

\section{Blood group}

$\mathrm{ABO}$ and Rhesus (RhD) blood groupings were determined for the study subjects. The most common blood type was $0+(32.4 \%)$ followed by blood type $A+(30.8 \%)$ and $B+(23.2 \%)$. $A B+$ was found $10 \%$. Only $9(3.6 \%)$ of the blood donors were RhD negative with blood group $A(1.6 \%), O(0.8 \%), B(0.8 \%)$ and $A B$ $(0.4 \%)$.

\section{Hematological parameters of the study subjects}

To obtain reliable results both parametric and non-parametric analysis were performed. The mean standard deviation, median and the 95th percentile reference ranges were determined. The distributions of RBC were statistically different by gender; females had lower values than males $(p<0.05)$. Statistically significant higher WBC $(p=0.027)$, platelet $(p=0.008)$, absolute neutrophil $(p=0.023)$, and absolute lymphocyte count $(p=0.026)$, were found in females (Table 1$)$.

One sample t-test was conducted to compare the mean hematological parameters of study participant with that of a reference value in current clinical use. In almost all cases absolute value of calculated- $t$ value is greater than tabulated- $t$ value; indicating that there was statistically significant variation between values in current study and text book reference range at $95 \%$ confidence interval (table 2). 
Mann-Whitney Test was conducted if there is significant variation in blood parameters in males between two age groups. There was no significant variation observed across the age groups $(p>0.05)$ (table 3$)$.

\section{Discussion}

In this study, $O$ positive blood group was predominant followed by $A$ and $B$ blood groups while $A B$ was the least frequently occurred. This is in line with other studies done in United States, Hispanics ${ }^{8}$ and Tanzania ${ }^{9}$. Rh negative blood group is documented as $2 \%$ in Tanzania ${ }^{9}, 2.9$ in Ethiopia ${ }^{10}$. In this study $3.6 \%$ of the subjects were Rh negative.

The WBC and neutrophil reference intervals in the current study was consistent with previously reported values from Addis Ababa, and United States based reference interval ${ }^{7,11,12}$, while higher than the values described for African population $6,13,14$. Lymphocyte count in the current study was comparable with Africa reference values, while lower than Caucasians ${ }^{12}$. The difference between the current result and other findings might be due to geographical differences, diet and ethnic background.

Regarding platelet counts, high reference range values were observed as compared with the findings of earlier studies in Ethiopia ${ }^{7}, K_{\text {Kenya }}{ }^{6}$ and Uganda ${ }^{15}$. However, the values are comparable with United States based reference value. The reason for the differences observed with the other studies is still unclear and may require additional studies but may be due to dietary, environmental and genetic factors. Such differences indicate the need to develop reference values that are appropriate for the applicable population.

Results of this study showed that there were significant differences in the values of WBC, RBC, lymphocyte, neutrophil and platelet count between male and female population. The mean and median RBC values were higher for men than women. Such difference by gender is in line with the findings of Ethiopian studies 7, 10, 13, 16, 17, 18 as well as other African studies $20,21,22$. The differences noted for RBC may be attributed to gender based hormonal variations. The higher values in males may be due to the influence of the hormone androgen on erythropoiesis, and females having lower levels is partly because of menstrual blood loss.

Compared to males, females had significantly higher WBC, neutrophil, and lymphocyte counts than males. This result is in agreement with the West Kenyan ${ }^{23}$ report which showed as there were significant differences in WBC, neutrophil, and lymphocyte counts between male and female adolescents ${ }^{23}$. Similarly gender differences in WBC, neutrophil and lymphocyte counts were found with females having higher values than males and this increase in neutrophil counts observed in women may be related to estrogen since a decrease in counts has been reported after menopause ${ }^{14,24}$. In contrary to the current study, a study done in Togo noticed that there were no gender differences in WBC count ${ }^{7,25}$, absolute neutrophil count, and absolute lymphocyte count ${ }^{26}$. This could possibly be attributed to environmental, genetic, and dietary variation. 
This study showed that platelet counts were significantly higher in females compared to male population. Such differences by gender are seen on previous reports from Ethiopia ${ }^{16,17}$ and different parts of the world $21,22,27$. This is in line with an observation that was reported in a Nigerian study conducted at the University of Port Harcourt Teaching Hospital ${ }^{28}$, as well as a study done in Western Kenya ${ }^{23}$. Similarly gender-based statistically significant differences in platelet count were observed from Tanzanian study. The females had significantly higher platelet count, whereas the males had lower platelet count ${ }^{14}$. Higher platelet counts in females compared to males might be due to the variations in hormone types where estradiol has been demonstrated to trigger platelet formation in megakaryocytic cell. Our study was not in agreement with study by Menard ${ }^{25}$ and Tsegaye et $\mathrm{al}^{7}$.

In the present study no significant variation was observed in hematological parameters between different age groups (Table 3 ). This is in agreement with other study which also reported no change in blood cells with aging ${ }^{29}$. However Odhiambo et al. ${ }^{23}$ reported significant differences in the hematological indices among males by age, with the young adults having a higher median of RBC as compared to adolescents as a result of accelerated growth ${ }^{23}$. In addition, a previous study also observeda significant decrease in RBC count ${ }^{30}$. A study from Germany also compared individuals below and beyond the age of 60 , and found statistically significant age-dependent decline in RBC counts for both genders. Reduced numbers of hematopoietic stem cells, a defect in progenitor cell proliferation ${ }^{31}$ and the lack of hormonal stimulation or the reduced response to hormonal stimulation have been described as some of the factors affecting hematological parameters in the elderly ${ }^{32}$. It should be noted that the maximum age of the participants in our study was 48 and this may be the reason for not finding difference in hematological parameters between different age groups.

\section{Conclusion}

The hematological reference values established in this study was significantly different from those reported in other countries as well as text books. Thus our data confirms the importance of population specific hematological parameters and supports the need for local guidelines rather than adoption of generalized reference values.

\section{Limitations of the study}

Although this study meets the minimum Clinical and Laboratory standards Institute requirements for establishing valid reference ranges, there are few limitations in this study that could be cited such as data on socioeconomic status, use of multivitamins and contraceptives were not available for all reference population. Despite our efforts to only include healthy subjects, it was not feasible to screen for all medical conditions that might have influenced the laboratory results.

\section{Declarations}




\section{Ethical approval and consent to participate}

Ethical clearance was obtained from Research and Ethics Review Committee of the Department of Medical Physiology, School of Medicine, College of Health Sciences, Addis Ababa University, Ethiopia. Detailed explanations were given about the objectives of the study to the study subjects. Strict confidentiality was maintained during the study. Data was collected after obtaining written informed consent from the study subjects. Only subjects who signed the consent were participated in the study.

\section{Consent for publication}

Not applicable

\section{Availability of data and material}

We can provide the data if reasonably needed.

\section{Competing interest}

The authors do not have any conflict of interest regarding this article.

\section{Funding}

This work did not receive any specific grant from funding agencies.

\section{Authors' contributions}

All authors are participated in the design of the study, collecting and analyzing the data. Mr. Mekuriaw, Mr. Dessalegn, Mr.Biruk and Mr. Sefialem prepared the manuscript. All authors read and approved the final manuscript.

\section{Acknowledgement}

We would like to express our sincere gratitude to Debre Markos Blood Bank for collecting data from the donors and the laboratory technologists of Debre Markos hospital for their part in performing complete blood count analysis. We also deeply express our thanks to the blood donors participated in this study.

\section{References}


1. Press A. The international federation of clinical chemistry. Clin Chim Acta. 1978;83:189F-202F.

2. Lugada ES, Mermin J, Kaharuza F, Ulvestad E, Were W, Langeland N, et al. Population-based hematologic and immunologic reference values for a healthy Ugandan population. Clin Diagn Lab Immunol. 2004;11(1):29-34.

3. Koram K, Addae M, Ocran J, Adu-Amankwah S, Rogers W, Nkrumah F. Population based reference intervals for common blood haematological and biochemical parameters in the Akuapem north district. Ghana medical journal. 2007;41(4).

4. Kratz A, Lewandrowski KB. Normal reference laboratory values. New England Journal of Medicine. 1998;339(15):1063-72.

5. Lim E, Miyamura J, Chen JJ. Racial/ethnic-specific reference intervals for common laboratory tests: a comparison among Asians, Blacks, Hispanics, and White. Hawai'i Journal of Medicine \& Public Health. 2015;74(9):302.

6. Kibaya RS, Bautista CT, Sawe FK, Shaffer DN, Sateren WB, Scott PT, et al. Reference ranges for the clinical laboratory derived from a rural population in Kericho, Kenya. PloS one. 2008;3(10):e3327.

7. Tsegaye A, Messele T, Tilahun T, Hailu E, Sahlu T, Doorly R, et al. Immunohematological reference ranges for adult Ethiopians. Clin Diagn Lab Immunol. 1999;6(3):410-4.

8. Garratty G, Glynn SA, McEntire R, Study RED. ABO and Rh (D) phenotype frequencies of different racial/ethnic groups in the United States. Transfusion. 2004;44(5):703-6.

9. Jahanpour O, Pyuza JJ, Ntiyakunze EO, Mremi A, Shao ER. ABO and Rhesus blood group distribution and frequency among blood donors at Kilimanjaro Christian Medical Center, Moshi, Tanzania. BMC research notes. 2017;10(1):738.

10. Haileamlak A, Muluneh AT, Alemseged F, Tessema F, Woldemichael K, Asefa M, et al. Hematoimmunological profile at gilgel gibe field research center, southwest Ethiopia. Ethiopian journal of health sciences. 2012;22(4):39-50.

11. Wintrobe MM, Greer JP. Wintrobe's Clinical Hematology. 2009.

12. Wayne P. Defining, establishing and verifying reference intervals in the clinical laboratory; approved guideline. Clinical and laboratory Standards Institute. 2008.

13. Karita E, Ketter N, Price MA, Kayitenkore K, Kaleebu P, Nanvubya A, et al. CLSI-derived hematology and biochemistry reference intervals for healthy adults in eastern and southern Africa. PloS one. 2009;4(2):e4401.

14. Saathoff E, Schneider P, Kleinfeldt V, Geis S, Haule D, Maboko L, et al. Laboratory reference values for healthy adults from southern Tanzania. Tropical Medicine \& International Health. 2008;13(5):612-25

15. Eller LA, Eller MA, Ouma B, Kataaha P, Kyabaggu D, Tumusiime R, et al. Reference intervals in healthy adult Ugandan blood donors and their impact on conducting international vaccine trials. PloS one. 2008;3(12):e3919.

16. Yalew A, Terefe B, Alem M, Enawgaw B. Hematological reference intervals determination in adults at Gondar university hospital, Northwest Ethiopia. BMC research notes. 2016;9(1):483. 
17. Eshete EA, Weldemariam TZ. Hematological and lipid profiles of blood donors at red cross center in Addis Ababa. Ethiopian medical journal. 2016 Jan 15;54(1).

18. Abera B, Alem A, Cherenet A, Kibret M. Immunological and hematological reference values for apparently healthy HIV-negative adults in Bahir Dar Town, Ethiopia. Ethiopian Journal of Health Development. 2012;26(3):152-9.

19. Alemnji G, Mbuagbaw J, Folefac E, Teto G, Nkengafac S, Atems N, et al. Reference physiological ranges for serum biochemical parameters among healthy Cameroonians to support HIV vaccine and related clinical trials. African Journal of Health Sciences. 2010;17(3\&4):75-82.

20. Gomani P, Matubu AT, Mujuru HA, Munjoma MW, Tinago W, Mandozana G, et al. Hematological and biochemical laboratory reference intervals for Zimbabwean adolescents. Clin Lab. 2015;61(12):101-11.

21. Tembe N, Joaquim O, Alfai E, Sitoe N, Viegas E, Macovela E, et al. Reference values for clinical laboratory parameters in young adults in Maputo, Mozambique. PloS one. 2014;9(5):e97391.

22. Dosoo DK, Kayan K, Adu-Gyasi D, Kwara E, Ocran J, Osei-Kwakye K, et al. Haematological and biochemical reference values for healthy adults in the middle belt of Ghana. PloS one. 2012;7(4):e36308.

23. Odhiambo C, Oyaro B, Odipo R, Otieno F, Alemnji G, Williamson J, et al. Evaluation of locally established reference intervals for hematology and biochemistry parameters in Western Kenya. PloS one. 2015;10(4):e0123140.

24. Zeh CE, Odhiambo CO, Mills LA. Laboratory reference intervals in Africa. Blood Cell: An Overview of Studies in Hematology. 2012:303.

25. Menard D, Mandeng MJ, Tothy MB, Kelembho EK, Gresenguet G, Talarmin A. Immunohematological reference ranges for adults from the Central African Republic. Clin Diagn Lab Immunol. 2003;10(3):443-5.

26. Kueviakoe IM, Segbena AY, Jouault H, Vovor A, Imbert M. Hematological reference values for healthy adults in Togo. ISRN hematology. 2010;2011

27. Hong J, Min Z, Bai-shen P, Jie Z, Ming-ting P, Xian-zhang H, Xiao-ke H, Lan-lan W, Xin Z, Wei G, Rui Q. Investigation on reference intervals and regional differences of platelet indices in healthy Chinese Han adults. Journal of clinical laboratory analysis. 2015 Jan;29(1):21-7.

28. Buseri F, Jeremiah Z. Reference values of hematological indices of infants, children, and adolescents in Port Harcourt, Nigeria. Pathol Lab Med Int. 2010;2:65-70.

29. Corberand J, Laharrague P, Fillola G. Blood cell parameters do not change during physiological human ageing. Gerontology. 1987;33(2):72-6.

30. Jain P, Jain R, Shah C, Trivedi R, Jain A, Jindal M, et al. A Prospective Study for Comparison of Hematological Parameters In Healthy Young Adult And Elderly Age Group Subjects. Gerontology. 2013;1(2):3.

31. Lipschitz D, Udupa K, Milton K, Thompson C. Effect of age on hematopoiesis in man. Blood. 1984;63(3):502-9. 
32. Mahlknecht U, Kaiser S. Age-related changes in peripheral blood counts in humans. ExpErimEntal and thErapEutic mEdicinE. 2010;1(6):1019-25.

\section{Tables}

Table 1: Mean, standard deviation and 95th percentile reference ranges of hematological parameters of male and female blood donors in Debre Markos, North West Ethiopia, 2016.

\begin{tabular}{|c|c|c|c|c|c|}
\hline \multirow[t]{2}{*}{ Parameter } & \multicolumn{2}{|l|}{ Male(n=192) } & \multicolumn{2}{|l|}{$\begin{array}{l}\text { Female } \\
(n=58)\end{array}$} & \multirow{2}{*}{$\begin{array}{l}\text { P-value } \\
\text { of } \\
\text { median }\end{array}$} \\
\hline & Mean \pm SD & $\begin{array}{l}\text { Median (2.5th } \\
-97.5 \text { th) }\end{array}$ & Mean \pm SD & $\begin{array}{l}\text { Median ( } \\
2.5 \text { th } \\
-97.5 \text { th) }\end{array}$ & \\
\hline WBC $(\times 103 / \mu \mathrm{L})$ & $6.34 \pm 1.82$ & $\begin{array}{l}6.20(3.47- \\
10.40)\end{array}$ & $6.96 \pm 1.89$ & $\begin{array}{l}6.75(3.25- \\
12.12)\end{array}$ & $0.027 *$ \\
\hline $\begin{array}{l}\text { Lymphocyte(abs) } \\
(\times 103 / \mu \mathrm{L})\end{array}$ & $2.09 \pm 0.64$ & $\begin{array}{l}2.00(1.20- \\
3.65)\end{array}$ & $2.27 \pm 0.68$ & $\begin{array}{l}2.20(1.04- \\
4.36)\end{array}$ & $0.026^{*}$ \\
\hline $\operatorname{Mid}(a b s)(\times 103 / \mu L)$ & $0.68 \pm 0.36$ & $\begin{array}{l}0.60(0.20- \\
1.70)\end{array}$ & $0.70 \pm 0.37$ & $\begin{array}{l}0.60(0.30- \\
2.07)\end{array}$ & 0.429 \\
\hline $\begin{array}{l}\text { Neutrophil(abs) } \\
(\times 103 / \mu \mathrm{L})\end{array}$ & $3.57 \pm 1.47$ & $\begin{array}{l}3.40(1.20- \\
6.72)\end{array}$ & $3.99 \pm 1.38$ & $\begin{array}{l}3.95(1.44- \\
8.22)\end{array}$ & $0.023^{*}$ \\
\hline Lymphocyte (\%) & $34.37 \pm 9.58$ & $\begin{array}{l}33.15(15.80- \\
56.75)\end{array}$ & $33.36 \pm 8.15$ & $\begin{array}{l}32.10(19.80- \\
53.71)\end{array}$ & 0.423 \\
\hline $\operatorname{Mid}(\%)$ & $10.81 \pm 4.45$ & $\begin{array}{l}9.40(5.68- \\
23.37)\end{array}$ & $10.14 \pm 3.63$ & $\begin{array}{l}9.00(5.59- \\
21.50)\end{array}$ & 0.38 \\
\hline Neutrophil (\%) & $54.83 \pm 10.67$ & $\begin{array}{l}56.10(30.75- \\
76.02)\end{array}$ & $56.50 \pm 9.24$ & $\begin{array}{l}57.45(34.55- \\
71.56)\end{array}$ & 0.206 \\
\hline $\mathrm{RBC}(\times 106 / \mu \mathrm{L})$ & $5.13 \pm 0.49$ & $\begin{array}{l}5.14(4.21- \\
6.17)\end{array}$ & $4.57 \pm 0.36$ & $\begin{array}{l}4.58(3.85- \\
5.32)\end{array}$ & $0.000 *$ \\
\hline Platelet $(\times 103 / \mu \mathrm{L})$ & $255.86 \pm 65.96$ & $\begin{array}{l}247.50 \\
(154.78- \\
418.88)\end{array}$ & $280.67 \pm 65.71$ & $\begin{array}{l}276.50 \\
(175.23- \\
425.68)\end{array}$ & $0.008^{*}$ \\
\hline MPV (fL) & $9.12 \pm 0.95$ & $\begin{array}{l}9.05(7.60- \\
11.02)\end{array}$ & $9.48 \pm 1.11$ & $\begin{array}{l}9.30(8.04- \\
13.44)\end{array}$ & $0.022^{*}$ \\
\hline
\end{tabular}

Abs =absolute, Mid =mid- sized cells (including monocyte, eosinophil and basophil), SD- standard deviation, MPV- mean platelet volume

* $P$ <0.05: statistically significant difference between males and females *Mann-Whitney test for differences between males and females. 
Table 2: Comparison of the mean of hematological parameters of the present study with that of a reference value in current clinical use.

\begin{tabular}{lllll} 
Parameter & Mean present & $\begin{array}{l}\text { Mean reference } \\
(\text { Wintrobe and Greer, 2009) }\end{array}$ & t-tabulated & t-calculated \\
\hline Hgb $(\mathrm{g} / \mathrm{dL})$ & & 14.3 & 0.000 & 15.6 \\
\hline Male & 16.3 & 14.0 & 0.001 & 3.6 \\
\hline Female & 14.6 & & & \\
\hline Hct $(\%)$ & & 46.0 & 0.04 & 2.0 \\
\hline Male & 46.7 & 42.0 & 0.08 & -0.2 \\
\hline Female & 41.9 & & & \\
\hline Rbc $(\times 106 / \mu \mathrm{L})$ & & 5.4 & 0.000 & -7.6 \\
\hline Male & 5.1 & 4.8 & 0.000 & 45.4 \\
\hline Female & 4.6 & 91 & 0.2 & 1.2 \\
\hline MCV $(\mathrm{fL})$ & 91.3 & 31 & 0.000 & 6.5 \\
\hline MCH $(\mathrm{pg})$ & 31.8 & 34 & 0.000 & 9.8 \\
\hline MCHC $(\mathrm{g} / \mathrm{dL})$ & 34.8 & 12.8 & 0.03 & -2.2 \\
\hline RDW $(\%)$ & 12.6 & 7.2 & 0.000 & -6.2 \\
\hline WBC $(\times 103 / \mu \mathrm{L}$ & 6.3 & 280 & 0.000 & -4.4 \\
\hline PLT $(\times 103 / \mu \mathrm{L})$ & 249 & 8.9 & 0.000 & 4.8 \\
\hline MPV & 9.2 & & & \\
\hline
\end{tabular}

* $\mid$ Calculated- $\mathrm{t}|>| \mathrm{t}$-tabulated $\mid$ is assumed significant, mean reference= mean of a reference value, mean present $=$ mean of present study

Table 3: Median and 95th percentile reference ranges of male blood donors between age group1 and Group 2 in Debre Markos, North West Ethiopia, 2016. 


\begin{tabular}{|c|c|c|c|}
\hline \multirow[t]{2}{*}{ Parameter } & Median (2.5th -97.5th) & \multirow[b]{2}{*}{ Age G2(36-48) N=11 } & \multirow[b]{2}{*}{$P$ value } \\
\hline & Age G1(18-35) N=181 & & \\
\hline WBC $(\times 103 / \mu \mathrm{L})$ & $6.10(3.41-10.40)$ & $7.60(4.50-)$ & 0.099 \\
\hline Lymphocyte (abs ) & $2.00(1.20-3.74)$ & $1.90(1.40-)$ & 0.531 \\
\hline \multicolumn{4}{|l|}{$(\times 103 / \mu \mathrm{L})$} \\
\hline $\operatorname{Mid}(\mathrm{abs})(\times 103 / \mu \mathrm{L})$ & $0.60(0.20-1.70)$ & $0.60(0.30-)$ & 0.835 \\
\hline Neutrophil (abs) & $3.30(1.20-6.65)$ & $4.90(2.50-)$ & 0.190 \\
\hline \multicolumn{4}{|l|}{$(\times 103 / \mu \mathrm{L})$} \\
\hline Lymphocyte (\%) & $33.50(15.80-57.30)$ & 27.20 (18.50-) & 0.370 \\
\hline $\operatorname{Mid}(\%)$ & $9.50(5.66-23.48)$ & $8.80(5.90-)$ & 0.144 \\
\hline Neutrophil (\%) & $55.20(30.67-76.05)$ & 63.10 (52.70-) & 0.061 \\
\hline $\mathrm{RBC}(\times 106 / \mu \mathrm{L})$ & $5.13(4.23-6.20)$ & $5.36(3.87-)$ & 0.383 \\
\hline Platelet $(\times 103 / \mu \mathrm{L})$ & $248.00(152.85-420.25)$ & $222.00(162.00-)$ & 0.146 \\
\hline MPV (fL) & $9.10(7.60-11.05)$ & $8.80(7.90)$ & 0.228 \\
\hline
\end{tabular}

abs =absolute, Mid =mid- sized cells (including monocyte, eosinophil and basophil), MPV- mean platelet volume, G1-group 1, G2-group 2. 